\title{
MICROBIAL DEGRADATION OF AN OIL POLLUTED SITE IN ABULE-EGBA, NIGERIA
}

\author{
Egbeja, T. $\mathrm{I}^{1}$, Bada, B. ${ }^{2 *}$, Arowolo, T. A $^{3}$ and Obuotor, T. $\mathrm{M}^{4}$ \\ ${ }^{123}$ Department of Environmental Management and Toxicology, \\ ${ }^{4}$ Department of Microbiology, Federal University of Agriculture, P.M.B 2240, Abeokuta, Ogun State, Nigeria. \\ Email addresses: tsobaza7@gmail.com¹,badabs@funaab.edu.ng ${ }^{2 *}$, tarowolo@yahoo.com³ and \\ tolumikoya@yahoo.com.*Corresponding author's Tel: +2348037250964 \\ (Received: $28^{\text {th }}$ December, 2017; Accepted: $24^{\text {th }}$ December, 2018)
}

\section{ABSTRACT}

\begin{abstract}
A pilot study was carried out on soil collected from Abule-Egba oil-pipeline in an area where pipeline vandalization was common to determine the effect of pig dung on microbiological composition and total petroleum hydrocarbon degradation. Top soil (0-15 cm depth) samples were randomly collected and one kilogram of the gasoline polluted-soil was measured into each of nine plastic containers. Pig dung was mixed with the soil at the rate of 0,50 and $100 \mathrm{~g} \mathrm{~kg}_{-}{ }^{1}$ soil in triplicate and the containers were arranged in a completely randomized design. Soil samples were taken from each container at 21 and 42 days for hydrocarbon utilizing bacteria and total petroleum hydrocarbon determination using standard methods. Data were subjected to descriptive and inferential statistics. The species identified were Bacillus, Staphylococcus, Escherichia, Pseudomonas and Enterobacter. The total petroleum hydrocarbon $\left(\mathrm{mg} \mathrm{kg}^{-1}\right)$ of the soil before pig dung application was $6.39 \pm 0.11$. After the amendments (at 0,50 and $\left.100 \mathrm{~g} \mathrm{~kg}^{-1}\right)$, the total petroleum hydrocarbon (mg $\left.\mathrm{kg}^{-1}\right)$ values were $3.25 \pm 0.17,0.03 \pm 0.01,0.03 \pm 0.01$ and $1.58 \pm 0.10,0.03 \pm 0.01,0.03 \pm 0.01$ for 21 and 42 days respectively. Pig dung significantly enhanced the biodegradation process as an impressive $99 \%$ remediation efficiency was achieved 21 days after amendment.
\end{abstract}

Keywords: Degradation, Hydrocarbon, Pig dung, Polluted soil

\section{INTRODUCTION}

Environmental pollution with crude oil and petroleum products has become a serious problem in Nigeria (Alexander, 2000). Most components of oil are toxic to human and wildlife because it's not only incorporated into the food chain, but also have a direct impact on species and habitats, which may set off a cascade of perturbations that affect the entire food chain. For this reason, scientists have focused their interest on examining the distribution, fate and behaviour of oil and its derivatives in the environment (Alexander, 2000; Semple et al., 2001).

The uncontrolled release of petroleum and its derivative products into soils and groundwater has become a significant problem globally, especially in Nigeria. A number of technologies have been tested to remediate polluted sites. Commonly used methods for soil remediation include mechanical, burying, evaporation, dispersion, and soil washing (Das and Chandra, 2011). Research has shown that these methods are capital intensive and result to partial degradation of contaminants (Das and Chandra, 2011). It has been proposed that bioremediation of petroleum hydrocarbons is an effective, economic, and environmentally friendly technology (Mulligan et al., 2001; Bundy et al., 2002; Bento et al., 2005; Joo et al., 2008; Gallego et al., 2010). Amendment of soil with organic or inorganic nitrogen-rich nutrients in a process known as biostimulation is an effective strategy to enhance the biodegradation process (Margesin et al., 2007). The potential use of organic wastes derived from plants and animals have been investigated by few researchers. Such wastes include rice husk and coconut shell (Nyankanga et al., 2012), plantain peels and cocoa pod husk (Agbor et al., 2012), Moringa oleifera and soya beans (Danjuma et al., 2012) and animal organic wastes like cow dung, pig dung, poultry manure and goat dung (Yakubu, 2007; Adesodun and Mbagwu, 2008; Agarry et al., 2010; Agarry and Ogunleye, 2012) as biostimulation strategies for petroleum hydrocarbon biodegradation in polluted environments.

However, cost effective methods and environmentally friendly strategies of enhancing 
petroleum hydrocarbon biodegradation in soil necessitated this study. Since oil pipeline network is widespread across almost all the agro-ecological zones in Nigeria, oil spillages are no longer restricted to the oil producing zones. Incidences of crude oil spills at non-oil producing zones, and the consequent contamination of terrestrial ecosystems abound (Jidere and Akamigbo, 2009). Oil spills have degraded most arable lands and have turned hitherto productive areas into wastelands. With increasing soil infertility due to the destruction of soil micro-organisms, and dwindling agricultural productivity, farmers have been forced to abandon their land, to seek nonexistent alternative means of livelihood.

In a study on the effect of oil spill on crop production, Chindah and Braide (2000) reported that oil spill on crops caused great damage to the plant community due to high retention time of oil occasioned by limited flow. In fact, oiled shoots of crops like pepper and tomatoes may wilt and die off due to blockage of stomata thereby inhibiting photosynthesis, transpiration and respiration. Germination, growth performance and yield of these crops are stifled by oil spillage (Odjuvwuederhie et al, 2006). Therefore, the objectives of this study are to assess effect of pig dung on the soil chemical properties and degradation of total petroleum hydrocarbon in soil polluted with gasoline.

\section{MATERIALS AND METHODS Samples Collection, Preparation and Experimental Design}

Pig dung was collected from Piggery Unit, Teaching and Research Farm, Federal University of Agriculture Abeokuta (FUNAAB), Nigeria. The manure was air dried, ground, mixed, sieved with a $2 \mathrm{~mm}$ sieve and stored in polythene bag.

Top soil $(0-15 \mathrm{~cm}$ depth) was collected from Abule-Egba oil-pipeline in an area where pipeline vandalization was common (Latitude $6^{\circ} 39^{\prime} 4.6714^{\prime \prime}$ $\mathrm{N}$ and Longitude $3^{\circ} 71^{\prime} 59.834^{\prime \prime} \mathrm{E}$ ) in Lagos State, Nigeria using a soil auger. The soil was air dried in a clean, well ventilated laboratory, homogenized by crushing and sieved by passing through a $2 \mathrm{~mm}$ mesh sieve. One kilogram of soil was measured into nine clean dry containers of three litres each
Pig dung was applied at the rate of 0 (control), 50 and $100 \mathrm{~g} \mathrm{~kg}^{-1}$ soil in triplicate. The pig dung was thoroughly mixed with the soil and the nine containers were arranged in a Completely Randomized Design in a greenhouse. Soil samples were taken from each container at 0 (zero day refers to the day pig dung was added to the soil), 21 and 42 days for $\mathrm{pH}$, organic carbon, nitrogen, phosphorus, potassium, hydrocarbon degrading bacteria count, hydrocarbon utilizing bacteria and total petroleum hydrocarbon determination.

\section{Laboratory Analysis \\ Soil Chemical Properties}

The $\mathrm{pH}$, organic carbon, total nitrogen, potassium and available phosphorus were determined in the soil samples using the methods described in Chopra and Kanwar (2011).

\section{Cultural Characterization of Bacteria}

Pure cultures of representative bacteria colonies were randomly picked from inoculated plates and were grouped on the basis of their colonial characteristics such as colony elevation, colour, size, opacity, shape, consistency, and edge (Barnett and Hunter, 1985).

\section{Morphological Characterization of bacteria}

Cultural grouping was followed by microscopic examination of isolates for cellular morphology. Day-old cultures of the bacteria isolates were stained with cotton blue lacto-phenol blue and observed microscopically for cell shape, size and sporulation (Barnett and Hunter, 1985).

\section{Biochemical Characterization of Bacteria}

A modified method of Cheesbrough (2006) was used for Gram staining, catalase test, urease test, citrate utilization test, indole test, motility test, coagulase test and sugar fermentation test.

\section{Determination of Total Hydrocarbon Utilizing Bacteria Count}

Total hydrocarbon utilizing bacteria count was carried out on mineral salt medium (MSM) agar as described by Balogun and Fagade (2010); and the isolated microorganisms were identified using Bergey's manual of systemic bacteriology (Krieg and Holt, 1984). 


\section{Determination of Total Petroleum Hydrocarbon}

Ten grams of the petroleum products-polluted soil sample was weighed into a clean bottle and 25 $\mathrm{ml}$ of dichloromethane was added, the mixture was allowed to stand on a mechanical shaker for a period of 3- 4 hours. The procedure was repeated twice and the aliquots were collected and mixed together in a beaker. The aliquots were concentrated on a steam bath reducing the extracts to about $5 \mathrm{ml}$. The concentrate was passed through a pipette packed with anhydrous sodium sulphate on top of a glass wool to remove moisture and other impurities. The final extract was analysed using a Hewlett-Packard 5890 series GC system coupled to a mass spectrophotometer (VG TRIO 2000) to determine the quantity of total petroleum hydrocarbons.

The degradation of petroleum products was expressed as the percentage of petroleum products degraded in relation to the amount of the remaining fractions in the appropriate abiotic control samples (Equation 1). The biodegradation efficiency (BE) based on the decrease in the total concentration of hydrocarbons, was calculated using Equation 1 (Mohan et al., 2006).

$B E=100-\left(\frac{A_{s} \times 100}{A_{a c}}\right) \quad$ Equation 1

Where $A_{s}=$ total area of peaks in each sample, $A_{a c}$ $=$ total area of peaks in the appropriate abiotic control and efficiency BE $(\%)=$ biodegradation

\section{Statistical Analysis}

Data obtained were subjected to descriptive (mean and standard deviation) and inferential (ANOVA) statistics. Means were separated using Duncan Multiple Range Test (DMRT).

\section{RESULTS}

\section{Chemical Properties of Soils and Pig Dung}

The value of soil $\mathrm{pH}$, total nitrogen $(\mathrm{N})$, available phosphorous $(\mathrm{P})$, exchangeable potassium $(\mathrm{K})$, organic carbon (OC) and total petroleum hydrocarbon (TPH) determined before pig dung application were $7.2 \pm 0.10,1.80 \pm 0.04 \mathrm{~g} \mathrm{~kg}^{-1}$, $38.76 \pm 1.20 \mathrm{mg} \mathrm{kg}^{-1}, 0.38 \pm 0.11 \mathrm{Cmol} \mathrm{kg}^{-1}, 61.18$ $\pm 0.32 \mathrm{~g} \mathrm{~kg}^{-1}$ and $6.39 \pm 0.11 \mathrm{mg} \mathrm{kg}^{1}$ respectively (Table 1).

Table 1: Chemical Properties of Abule-Egba Soil without Pig Dung before Experiment

\begin{tabular}{ll}
\hline Parameters & Value \\
\hline $\mathrm{pH}$ & $7.2 \pm 0.10$ \\
Nitrogen $\left(\mathrm{g} \mathrm{kg}^{-1}\right)$ & $1.80 \pm 0.04$ \\
Available phosphorus $\left(\mathrm{mg} \mathrm{kg}^{-1}\right)$ & $38.76 \pm 1.20$ \\
Exchangeable potassium $\left(\mathrm{Cmol} \mathrm{kg}^{-1}\right)$ & $0.38 \pm 0.11$ \\
Organic Carbon $\left(\mathrm{g} \mathrm{kg}^{-1}\right)$ & $61.18 \pm 0.32$ \\
THDB $\left.(\mathrm{CFU} \mathrm{g})^{-1}\right)$ & $1.54 \times 104 \pm 0.5 \times 10^{4}$ \\
TPH $\left(\mathrm{mg} \mathrm{kg}^{-1}\right)$ & $6.39 \pm 0.11$ \\
\hline
\end{tabular}

THDB $=$ Total hydrocarbon degrading bacteria

$\mathrm{TPH}=$ Total petroleum hydrocarbon

The pig dung was high in organic carbon (51.00 \pm $\left.0.56 \mathrm{~g} \mathrm{~kg}^{-1}\right)$ and also contained total hydrocarbondegrading bacteria of $8.0 \times 10^{3} \pm 1.24 \times 10^{3} \mathrm{CFU}$ $\mathrm{g}^{-1}$ while the total petroleum hydrocarbon was below detection limit (Table 2). 
Table 2: Proximate Analysis of the Pig Dung

\begin{tabular}{ll}
\hline Parameters & Value \\
\hline $\mathrm{pH}$ & $7.9 \pm 1.23$ \\
Nitrogen $\left(\mathrm{g} \mathrm{kg}^{-1}\right)$ & $16.4 \pm 3.21$ \\
Phosphorus $\left(\mathrm{mg} \mathrm{kg}^{-1}\right)$ & $1.25 \pm 0.36$ \\
Potassium $\left(\mathrm{Cmol} \mathrm{kg}^{-1}\right)$ & $0.28 \pm 0.03$ \\
Organic Carbon $\left(\mathrm{g} \mathrm{kg}^{-1}\right)$ & $51.0 \pm 4.63$ \\
Moisture Content $(\%)$ & $92.2 \pm 6.42$ \\
THDB $\left(\mathrm{CFU} \mathrm{g-}{ }_{-}^{-1}\right)$ & $8.0 \times 10^{3} \pm 1.22 \times 10^{3}$ \\
TPH $\left(\mathrm{mg} \mathrm{kg}^{-1}\right)$ & BDL \\
\hline
\end{tabular}

THDB $=$ Total hydrocarbon degrading bacteria $\mathrm{TPH}=$ Total petroleum hydrocarbon $\mathrm{BDL}=$ Below detection limit

\section{Effect of Pig Dung Application on the Soil Chemical Properties}

Application of pig dung significantly $(p<0.05)$ increased $\mathrm{pH}$ of the contaminated soil compared to the control (without pig dung application) at 21 and 42 days (Table 3). The $\mathrm{pH}$ of soil before pig dung application was $7.90 \pm 0.10$ while control, 50 and $100 \mathrm{~g}$ of pig dung were $6.8 \pm 0.06$ and $6.7 \pm$ $0.20 ; 7.3 \pm 0.10$ and $7.2 \pm 0.06 ; 7.4 \pm 0.15$ and 7.2 \pm 0.06 for day 21 and 42 respectively indicating a downward trend. Total $\mathrm{N}$ of the soil $\left(\mathrm{g} \mathrm{kg}^{-1}\right)$ before pig dung application was 1.92 while control, 50 and $100 \mathrm{~g}$ of pig dung were $0.86 \pm 0.03$ and $0.72 \pm$ $0.06,1.41 \pm 0.07$ and $1.13 \pm 0.08,1.94 \pm 0.08$ and $1.57 \pm 0.09$ for 21 and 42 days respectively indicating a downward trend for the experimental. Significantly $(\mathrm{p}<0.05)$ lower N, P, K and organic carbon were recorded in 50 and $100 \mathrm{~g}$ pig dung kg${ }^{1}$ soil at 21 and 42 days respectively.

Table 3: Effects of Pig Dung Amendment on the Soil Chemical Properties

\begin{tabular}{lllllll}
\hline $\begin{array}{l}\text { Pig dung } \\
\text { level }(\mathrm{g})\end{array}$ & $\begin{array}{l}\text { Days after } \\
\text { amendment }\end{array}$ & $\mathrm{pH}$ & $\begin{array}{l}\text { Nitrogen } \\
\left(\mathrm{g} \mathrm{kg}^{-1}\right)\end{array}$ & $\begin{array}{l}\text { Phosphorus } \\
\left(\mathrm{mg} \mathrm{kg}^{-1}\right)\end{array}$ & $\begin{array}{l}\text { Potassium } \\
\left(\mathrm{Cmol} \mathrm{kg}^{-1)}\right)\end{array}$ & $\begin{array}{l}\text { Organic } \\
\text { carbon } \\
\left(\mathrm{g} \mathrm{kg}^{-1}\right)\end{array}$ \\
\hline 0 & 21 & $6.8 \pm 0.06^{\mathrm{c}}$ & $0.86 \pm 0.03^{\mathrm{f}}$ & $77.32 \pm 1.17^{\mathrm{e}}$ & $0.36 \pm 0.02^{\mathrm{d}}$ & $48.07 \pm 0.05^{\mathrm{c}}$ \\
& 42 & $6.7 \pm 0.20^{\mathrm{c}}$ & $0.72 \pm 0.06^{\mathrm{f}}$ & $64.92 \pm 2.46^{\mathrm{f}}$ & $0.14 \pm 0.02^{\mathrm{e}}$ & $40.34 \pm 0.63^{\mathrm{d}}$ \\
50 & 21 & $7.3 \pm 0.10^{\mathrm{ab}}$ & $1.41 \pm 0.07^{\mathrm{d}}$ & $151.15 \pm 2.55^{\mathrm{c}}$ & $1.01 \pm 0.23^{\mathrm{b}}$ & $57.10 \pm 0.16^{\mathrm{b}}$ \\
& 42 & $7.2 \pm 0.06^{\mathrm{b}}$ & $1.13 \pm 0.08^{\mathrm{e}}$ & $129.93 \pm 3.32^{\mathrm{d}}$ & $0.80 \pm 0.05^{\mathrm{c}}$ & $41.41 \pm 2.23^{\mathrm{d}}$ \\
100 & 21 & $7.4 \pm 0.15^{\mathrm{a}}$ & $1.94 \pm 0.08^{\mathrm{b}}$ & $202.30 \pm 4.23^{\mathrm{a}}$ & $1.56 \pm 0.03^{\mathrm{a}}$ & $61.24 \pm 0.68^{\mathrm{a}}$ \\
& 42 & $7.2 \pm 0.06^{\mathrm{b}}$ & $1.57 \pm 0.09^{\mathrm{c}}$ & $189.81 \pm 4.20^{\mathrm{b}}$ & $1.43 \pm 0.20^{\mathrm{b}}$ & $48.41 \pm 1.61^{\mathrm{c}}$ \\
\hline
\end{tabular}

Values are means \pm SD of three replicates. Different superscript in the same column indicate significant difference at $\mathrm{p}<0.05$ (Duncan's Multiple Range Test)

\section{Effect of Pig Dung on the Hydrocarbon Degrading Bacteria Counts and Identification}

The values of total hydrocarbon degrading bacteria decreased from 21 to 42 days in 0 (control), 50 and $100 \mathrm{~g}$ pig dung kg-1 soil (Table 4). The total hydrocarbon degrading bacteria were found to be higher in soil amended with pig dung than the control soil. Morphological characteristics of bacteria isolated from the polluted soil amended with pig dung at 42 days are presented in table 5 . The size of the bacteria ranged between $1-5 \mathrm{~mm}$. Most of the bacteria were irregular in shape, grey-white in colour, wet consistency, smooth edges, flat elevation and opaque. The types and relative abundance of microbial communities in microcosms due to natural attenuation and biostimulation treatment methods recorded in the contaminated soil are presented in table 6. Five hydrocarbon utilizing bacteria were identified from the polluted soil. The hydrocarbon degrading bacteria identified belong to the genera Bacillus, Staphylococcus, Escherichia, Pseudomonas and Enterobacter. Bacillus species were the most predominant isolated bacterial species across the treatments. 
Egbeja et al.: Microbial Degradation of An Oil Polluted Site

Table 4: Total Hydrocarbon Degrading Bacteria Count of the Polluted Soil Amended with Pig Dung

\begin{tabular}{lll}
\hline Pig dung level $(\mathrm{g})$ & Day & THDB $\left(\mathrm{CFU} \mathrm{g}^{-1}\right)$ \\
\hline 0 & 21 & $1.12 \times 10^{4} \pm 1.35 \times 10^{3 \mathrm{c}}$ \\
& 42 & $.63 \times 10^{3} \pm 1.99 \times 10^{3 \mathrm{c}}$ \\
50 & 21 & $.55 \times 10^{4} \pm 3.59 \times 10^{3 \mathrm{ab}}$ \\
& 42 & $2.40 \times 10^{4} \pm 1.44 \times 10^{3 \mathrm{bc}}$ \\
100 & 21 & $1.97 \times 10^{4} \pm 7.94 \times 10^{3 \mathrm{a}}$ \\
& 42 & $1.44 \times 10^{4} \pm 3.03 \times 10^{3 \mathrm{a}}$ \\
\hline
\end{tabular}

THDB $=$ Total Hydrocarbon Degrading Bacteria

Values are means \pm SD of three replicates. Different superscript in the same column indicate significant difference at $\mathrm{p}<0.05$ (Duncan's Multiple Range Test)

Table 5: Morphological Characteristics of Bacteria Isolated from the Polluted Soil

\begin{tabular}{llllllll}
\hline $\begin{array}{l}\text { Isolate } \\
\text { Code }\end{array}$ & $\begin{array}{l}\text { Size } \\
(\mathrm{mm})\end{array}$ & Shape & Colour & Consistency & Edges & Elevation & Opacity \\
\hline 0 g PD & $3-5$ & Irregular & Grey-white & Dry & Rough & Flat & Opaque \\
0 g PD & $1-2$ & Smooth & Yellow & Wet & Smooth & Slightly raised & Opaque \\
0 g PD & $3-4$ & Round & Grey-white & Wet & Smooth & Raised & Opaque \\
50 g PD & $2-3$ & Round & White & Wet & Smooth & Flat & Opaque \\
50 g PD & $3-4$ & Irregular & Green & Wet & Rough & Flat & Opaque \\
50 g PD & $3-4$ & Round & Grey-white & Wet & Smooth & Raised & Opaque \\
100 g PD & $2-3$ & Round & White & Wet & Smooth & Flat & Opaque \\
100 g PD & $1-2$ & Smooth & Yellow & Wet & Smooth & Slightly raised & Opaque \\
100 g PD & $3-5$ & Irregular & Grey-white & Dry & Rough & Flat & Opaque \\
\hline
\end{tabular}

Table 6: Types and Relative Abundance of Micro-organisms in the Polluted Soil

\begin{tabular}{|c|c|c|c|c|c|c|c|c|c|c|c|c|c|c|}
\hline $\begin{array}{l}\text { Isolate } \\
\text { code }\end{array}$ & GR & SP & $\mathrm{CP}$ & CA & $\begin{array}{l}\mathrm{C} \\
\mathrm{O}\end{array}$ & $\begin{array}{l}\mathrm{M} \\
\mathrm{O}\end{array}$ & $\begin{array}{l}\mathrm{I} \\
\mathrm{N}\end{array}$ & $\begin{array}{l}\mathrm{O} \\
\mathrm{X}\end{array}$ & $\mathrm{CI}$ & UR & MR & VP & G L M & $\begin{array}{l}\text { Probable } \\
\text { organism }\end{array}$ \\
\hline $\begin{array}{l}100 \mathrm{~g} \\
\text { PD }\end{array}$ & GPB & + & + & + & - & + & - & - & - & - & + & - & A - - & Bacillus subtilis \\
\hline $\begin{array}{l}100 \mathrm{~g} \\
\text { PD }\end{array}$ & GPC & - & - & + & + & - & - & - & - & - & - & + & A A A & Staph. Aureus \\
\hline $\begin{array}{l}100 \mathrm{~g} \\
\text { PD }\end{array}$ & $\begin{array}{l}\text { GN } \\
B\end{array}$ & - & - & + & - & + & - & - & + & - & + & - & A A - & Enterobactersp \\
\hline $\begin{array}{l}50 \mathrm{~g} \\
\mathrm{PD}\end{array}$ & $\begin{array}{l}\text { GN } \\
B\end{array}$ & - & - & + & - & + & + & - & - & - & + & - & A A - & Escherichia coli \\
\hline $\begin{array}{l}50 \mathrm{~g} \\
\mathrm{PD}\end{array}$ & $\begin{array}{l}\text { GN } \\
B\end{array}$ & - & - & + & - & + & - & + & + & - & + & - & $-\quad-\quad-$ & $\begin{array}{l}\text { Pseudomonas } \\
\text { aeruginosa }\end{array}$ \\
\hline $\begin{array}{l}50 \mathrm{~g} \\
\mathrm{PD}\end{array}$ & $\begin{array}{l}\text { GN } \\
B\end{array}$ & - & - & + & - & + & - & - & + & - & + & - & A A - & Enterobactersp \\
\hline $0 \mathrm{~g}$ PD & $\begin{array}{l}\text { GN } \\
B\end{array}$ & - & - & + & - & + & + & - & - & - & + & - & A A - & Escherichia coli \\
\hline $0 \mathrm{~g}$ PD & GPC & - & - & + & + & - & - & - & - & - & - & + & A A A & Staph. aureus \\
\hline $0 \mathrm{~g}$ PD & GPB & + & + & + & - & + & - & - & - & - & + & - & A - - & Bacillussubtilis \\
\hline
\end{tabular}

Keys: GR-Gram staining, SP- Spore staining, CA- Capsule staining, CT- Catalase, MO-Motility, IN- Indole, OX- Oxidase, CI- Citrate, IN- Indole, OX- Oxidase, CI- Citrate, UR- Urea, MR-

Methyl-red, VP- Vogesproskeur, G- Glucose, L- lactose, S- Sucrose, M-Mannitol, A-Acid production, $\mathrm{PD}=$ Pig dung, $\mathrm{g}=\mathrm{Gram},-=$ Absent,$+=$ Present, $\mathrm{A}=$ Abundant 


\section{Biodegradation and Kinetics of Total Petroleum Hydrocarbon in the Contaminated Soil}

Significantly $(p<0.05)$ higher concentration of total petroleum hydrocarbon was observed in $0 \mathrm{~g}$ pig dung $\mathrm{kg}^{-1}$ soil (control) at 21 days while the value that was recorded in $100 \mathrm{~g}$ pig dung $\mathrm{kg}_{-}{ }^{1}$ soil at 42 days was significantly $(p<0.05)$ lower (Table 7). Total petroleum hydrocarbon of the soil (mg $\mathrm{kg}^{-1}$ ) before pig dung application was $6.39 \pm 0.11$ while control, 50 and $100 \mathrm{~g}$ of pig dung were 3.25 \pm 0.17 and $1.58 \pm 0.10 ; 0.03 \pm 0.00$ and $0.03 \pm$ $0.00 ; 0.03 \pm 0.00$ and $0.03 \pm 0.00$. At 21 and 42 days after the amendment, highest total petroleum hydrocarbon reduction of $6.36 \mathrm{mg} \mathrm{kg}^{-1}(99.99 \%)$ was observed at 50 and $100 \mathrm{~g}$ pig dung $\mathrm{kg}^{-1}$ soil (Table 7) compared with an initial concentration of $6.39 \mathrm{mg} \mathrm{kg}^{-1}$ (Table 1). Concentration of total petroleum hydrocarbon in unamended soil (control) and their natural logarithm were plotted against time as shown in figures 1 and 2 in order to analyze the kinetics for the biodegradation process. The biodegradation process followed first order kinetics since the graph of total petroleum hydrocarbon concentration in soil against time had an exponential curve (Figure 1) and that of $\ln$ (natural logarithm) of total petroleum hydrocarbon concentration against time was linear (Figure 2). Rate constant was found to be 0.033 day- ${ }^{-1}$. Correlation analysis (r) for the petroleum products biodegradation kinetics process was 0.999 , indicating linearity and positive correlations for the decrease in concentration as a function of time.

Table 7: Rate of Change of Total Petroleum Hydrocarbon during Biodegradation of the Polluted Soil

\begin{tabular}{llllll}
\hline $\begin{array}{l}\text { Pig dung level } \\
(\mathrm{g})\end{array}$ & Time (days) & $\begin{array}{l}\mathrm{TPH} \\
\left(\mathrm{mg} \mathrm{kg}^{-1}\right)\end{array}$ & In TPH & $\begin{array}{l}\text { TPH } \\
\text { Degraded } \\
\left(\mathrm{mg} \mathrm{kg}^{-1}\right)\end{array}$ & $\begin{array}{l}\text { Degradation } \\
(\%)\end{array}$ \\
\hline 0 & 21 & $3.25 \pm 0.17^{\mathrm{a}}$ & 1.17 & 3.14 & 49.14 \\
& 42 & $1.58 \pm 0.10^{\mathrm{a}}$ & 0.45 & 4.81 & 75.27 \\
50 & 21 & $0.03 \pm 0.01^{\mathrm{bc}}$ & -3.51 & 6.36 & 99.99 \\
& 42 & $0.03 \pm 0.01^{\mathrm{bc}}$ & -3.51 & 6.36 & 99.99 \\
100 & 21 & $0.03 \pm 0.01^{\mathrm{bc}}$ & -3.51 & 6.36 & 99.99 \\
& 42 & $0.03 \pm 0.01^{\mathrm{bc}}$ & -3.51 & 6.36 & 99.99 \\
\hline
\end{tabular}

$\mathrm{TPH}=$ Total Petroleum Hydrocarbon

Values are means \pm SD of three replicates. Different superscript in the same column indicate significant difference at $\mathrm{p}<0.05$ (Duncan's Multiple Range Test)

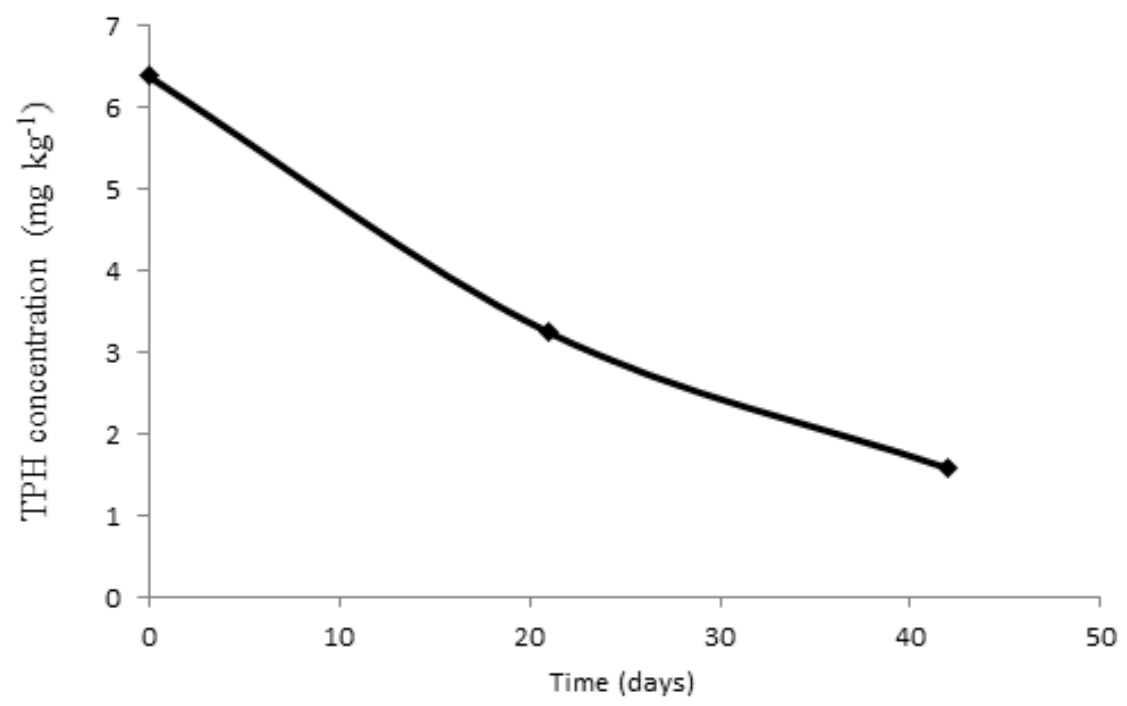

Figure 1: First Order Profile for the Biodegradation of the Unamended Polluted Soil 


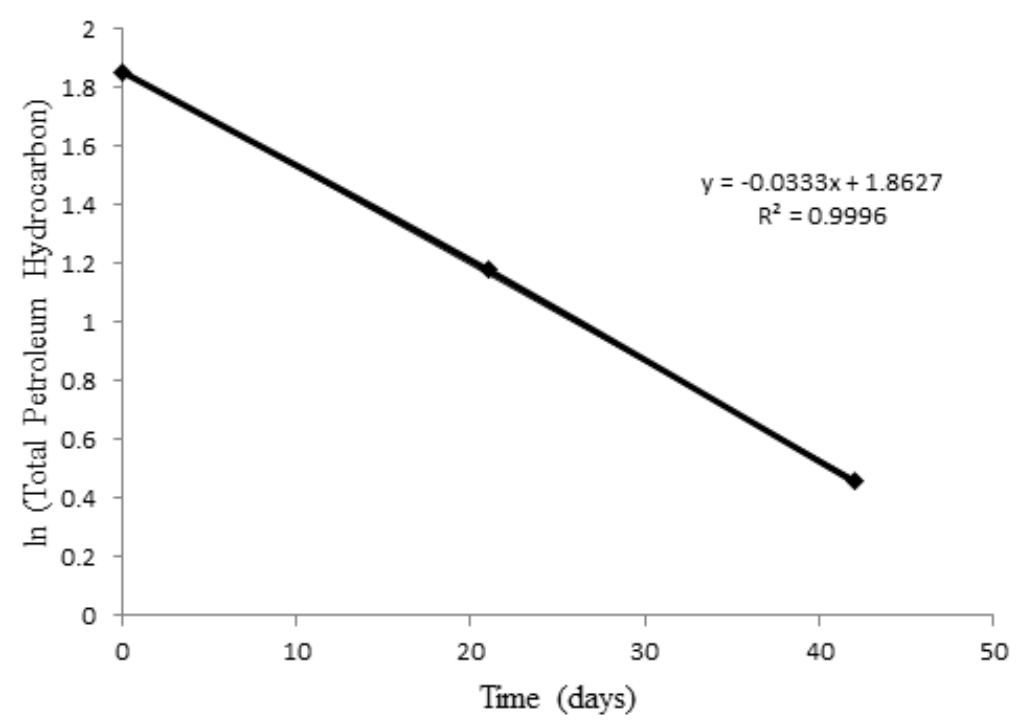

Figure 2: ln (Total Petroleum Hydrocarbon) against Time for the Biodegradation of the Unamended Polluted Soil

\section{DISCUSSIONS}

In this study, natural attenuation and biostimulation treatment method of Abule-Egba gasoline polluted soil was monitored with a view to gaining an insight into conditions necessary for petroleum hydrocarbon degradation. Application of pig dung significantly $(\mathrm{p}<0.05)$ increased $\mathrm{pH}$ of the polluted soil compared to the control at 21 and 42 days. Soil $\mathrm{pH}$ range between 6.9 and 7.5 is good for most hydrocarbon utilizing bacteria (Vidali, 2001; Yakubu, 2007).

The gradual decrease in $\mathrm{pH}$ as biodegradation progressed recorded in this study was not unconnected to the biodegradation process which removed the contaminant and introduced some salts and ions from pig dung (Akpoveta et al., 2011). The decrease in soil N, P, K and organic carbon content from 21 to 42 days at every pig dung level might be due to their high demand by microorganisms for sugar phosphorylation, nucleic acid synthesis and other cellular processes (Andrew and Jackson, 1996). It has also been reported that petroleum hydrocarbon contaminants could destroy inorganic nutrient sources by reacting with them along with other substances present in soil (Teal et al., 1992; Andrew and Jackson, 1996). The reduction in population of total hydrocarbon degrading bacteria from 21 to 42 days in 0 (control), 50 and $100 \mathrm{~g}$ pig dung $\mathrm{kg}^{-1}$ soil recorded in this study might be due to the fact that mineralization of hydrocarbons could have possibly resulted in the production of toxic metabolites which on introduction into the system reduces the growth phase of the microbes (Akpoveta et al., 2011).

Microorganisms generally require mineral nutrients sources for growth (Andrew and Jackson, 1996). If any of the required nutrients is lacking or becomes limiting, particularly the macro-mineral elements, microbial population will decrease (Giordani et al., 1998; Lehtola et al., 1998; Vidali, 2001). Akpoveta et al. (2011) also reported a decline in bacterial population as the biodegradation progressed. Bacillus species were the most predominant isolated bacterial species, its prevalence could be attributed to the fact that it forms spores, which help microorganisms to withstand harsh conditions. Isolation of Bacillus species from hydrocarbon contaminated soil amended with pig dung could also be attributed to its ubiquitous distribution in nature.

Mansour et al. (1999) reported the isolation of Bacillus, Acinetobacter, Staphylococcus and Enterobacter among other bacteria from hydrocarbon contaminated soil. The oil utilizing bacteria isolated from this study have previously been implicated in hydrocarbon biodegradation, though from different sources (Ijah and Antai, 2003; Yakubu, 2007). Degradation of total petroleum hydrocarbon in the contaminated soil amended with pig dung might be due to the 
bacterial consortium in the pig dung that attacked and degraded the components of the hydrocarbon (Yakubu, 2007; Adesodun and Mbagwu 2008). Higher significant concentration of total petroleum hydrocarbon was recorded in the soil without pig dung applications compared with the least significant $(p<0.05)$ value observed in $100 \mathrm{~g}$ pig dung $\mathrm{kg}^{-}{ }^{1}$ soil. Biostimulation has been reported as an important factor that enhances soil bioremediation (Cardona and Iturbe, 2003; Gallego et al., 2010).

Gallego et al. (2010) in their study of in situ bioremediation techniques reported that it is possible to degrade up to $90 \%$ of hydrocarbon pollutant, during biostimulation. The decrease in total petroleum hydrocarbon concentrations from 21 to 42 days could be that mineral elements in pig dung contributed to the enhanced biodegradation. The first order kinetics observed in the degradation process in this study could be attributed to the fact that as concentration of the contaminant in the soil was decreasing with time, the concentration degraded by the microbes was also increasing for the biodegradation study (Peijun et al., 1996; Akpoveta et al., 2011).

\section{CONCLUSION}

In this study, microcosm experiments were conducted to evaluate the effectiveness of pig dung on the bioremediation of fuel-oil contaminated soils. After 21 days of incubation, approximately $99 \%$ remediation efficiency was achieved at 50 and $100 \mathrm{~g}$ pig dung $\mathrm{kg}^{-1}$ soil. The results indicate that biostimulation of petroleumproducts contaminated soil resulted in the enhancement of petroleum hydrocarbon degradation. Pig dung is a reliable and powerful tool for fuel-oil contaminated soils bioremediation processes.

\section{REFERENCES}

Adesodun, J. K. and Mbagwu, J. S. C. 2008. Biodegradation of waste-lubricating petroleum oil in a tropical alfisol as mediated by animal droppings. Bioresource Technology, 99 (13): 56595665.

Agarry, S. E., Owabor, C. N. and Yusuf, R. O. 2010. Studies on biodegradation of kerosene in soil under different bioremediation strategies. Bioremediation Journal, 14 (3): 135-141.

Agarry, S. E. and Ogunleye, O. O. 2012. Boxbehnken designs application to study enhanced bioremediation of soil artificially contaminated with spent engine oil using biostimulation strategy. International Journal of Energy and Environmental Engineering, 3: 31-34.

Agbor, R. B., Ekpo, I. A., Osuagwu, A. N., Udofia, U. U., Okpako, E. C. and Antai, S. P. 2012. Biostimulation of microbial degradation of crude oil polluted soil using cocoa pod husk and plantain peels. Journal of Microbiology and Biotechnology Resources, 2(3): 464-469.

Akpoveta, O. V., Egharevba, F., Medjor, O. W., Osaro, K. I. and Enyemike, E. D. 2011. Microbial degradation and its kinetics on crude oil polluted soil. Resource Journal of Chemical Science, 1(6): 8-14.

Alexander, M. 2000. Aging, bioavailability and overestimation of risk from environmental pollutants.

Environmental Science Technology, 34: 4259-4265.

Andrew, R. W. J. and Jackson J. M. 1996. Environmental science: the natural environment and human impact. Longman Publishers, Singapore.

Balogun, S. A and Fagade, O. E. 2010. Emulsifying bacteria in produce water from NigerDelta, Nigeria. African Journal of Microbiology Research, 4(9): 730-734.

Barnett, H. I. and Hunter, B. B. 1985. Illustrated genera of imperfect fungi. $5^{\text {th }}$ edition. Burges Publishing Company. Minnesota.

Bento, F. M., Camargo, F. O., Okeke, B. and FrankenbergerJr., T. W. 2005. Comparative bioremediation of soils contaminated with diesel oil by natural attenuation, biostimulation bioaugmentation. Bioresources Technology, 96: 1049-1055.

Bundy, J. G., Paton, G. I. and Campbell, C. D. 2002. Microbial communities in different soils types do not converge after diesel contamination. Journal of Applied 
Microbiology, 92: 276-288.

Cardona, S. and Iturbe, R. 2003. Biodegradación de diesel mexicano por un consorcio de bacterias de un suelo. Agrícola, 138: 1326.

Cheesbrough, M. 2006. District Laboratory Practice in Tropical Countries. Part 1 ( $2^{\text {nd }}$ edition), Cambridge University Press, UK, pp. 143-157.

Chindah, A. C. and Braide, S. A. 2000. The impact of oil spills on the Ecology and Economy of the Niger Delta. In Proceedings of the workshop on Sustainable Remediation Development Technology held at the Institute of Pollution Studies, Rivers State University of Science and Technology, Port Harcourt.

Chopra, S. L. and Kanwar, J. S. 2011. Analytical Agricultural Chemistry. Kalyani publishers: New Delhi, pp. 152-195.

Danjuma, B. Y., Abdulsalam, S. and Sulaiman, A. D. I. 2012. Kinetic investigation of Escravos crude oil contaminated soil using natural stimulants of plant sources. International Journal of Emerging Trends in Engineering and Development, 2(5): 478-486.

Das, N. and Chandra, P. 2011. Microbial degradation of petroleum hydrocarbon contaminants: an overview. Biotechnology Resource International, 1-13.

Gallego, J. R., Loredo, J., Llamas, J. F., Vazquez, F. and Sanchez, J. 2010. Bioremediation of diesel-contaminated soils: evaluation of potential in situ techniques by study of bacterial degradation. Biodegradation, 12: 325-335.

Giordani, G., Donnelly, A. and Azzoni, R. 1998. The uptake of inorganic phosphate by Z. Noltii in the Basin d' Arcachon. In: Proceedings (Handbook) of Summer Conference of the Society for Applied Microbiology, University of Lancaster, UK, pp. 22-23.

Ijah, U. J. and Antai, S. P. 2003. The potential use of Chicken-drop microorganisms for oil spill remediation. The Environmentalist, 23: 89-95.

Jidere, C. M. and Akamigbo, F. O. 2009. The potentials of cowpea (Vigina unguiculata) and maize (Zea mays) to stimulate hydrocarbon degradation in soil. Journal of Tropical Agriculture, Food, Environment and Extension, 8(1): 24-33.

Joo, H. S., Ndegwa, P. M., Shoda, M. and Phae, C. G. 2008. Bioremediation of oilcontaminated soil using Candida catenulata and food waste. Journal of Environmental Pollution, 156: 891-896.

Krieg, N. R. and Holt, J. G. 1984. Bergey's Manual of Systematic Bacteriology. 1 Baltimore, Williams and Wilkins, Washington, USA.

Lehtola, M., Miettinen, I., Vartianen, T. and Martikainen, P. J. 1998. Purification of drinking water phosphorus and bacterial growth. In: Proceedings (Handbook) of Summer Conference of the Society for Applied Microbiology, University of Lancaster, UK), pp 16-17.

Margesin, R., Hammerle, M. and Tscherko, D. 2007. Microbial activity and community composition during bioremediation of diesel-oil-contaminated soil: Effects of hydrocarbon concentration, fertilizers, and incubation time. Microbial Ecology, 53:259-269.

Mansour, M., Bottefroy, D. and Linder, A. 1999. Inhibition of Bacillus lincheniformis spore growth in milk by nisin, monolaurin, and $\mathrm{pH}$ combinations. Journal of Applied Microbiology, 86: 311-324.

Mohan, S. V., Kisa, T., Ohkuma, T., Kanaly, R. A. and Shimizu, Y. 2006. Bioremediation technologies for treatment of $\mathrm{PAH}$ contaminated soil and strategies to enhance process efficiency. Reviews in Environmental Science and Biotechnology, 5(4):347-374.

Mulligan, C. N., Yong, R. N. and Gibbs, B. F. 2001. Surfactant enhanced remediation of contaminated soil: A review: England Geology (Amsterdam), 60:371-380.

Nyankanga, R. O., Onwonga, R. N., Wekesa, F. S., Nakimbugwe, D. and Masinde, D. 2012. Effect of inorganic and organic fertilizers on the performance and profitability of gGrain Amaranth (Amaranthus caudatus 
L.) in Western Kenya. Journal of Agricultural and Science, 4: 223-232.

Odjuvwuederhie, I., Donglason O. G. and Felicia, A. N. 2006. The effect of oil spillage on crop yield and farm income in Delta State of Nigeria. Journal of Central European Agriculture, 7(1):41-48.

Peijun, L., Tieheng S., Frank, S., Chungui, Z., Hairong, Z., Xianzhe, X., Graeme, A., Xuejun, M. and Sankaram, A. 1996. A laboratory manual for agricultural chemistry. Asia Publishing House, New Debli, 340.

Semple, K. T., Reid, B.J. and Fermor, T. R. 2001. Impact of composting strategies on the treatment of soils contaminated with organic pollutants. Environmental Pollution, 112 (1): 269-283.

Teal, J. M., Farrington, J. W., Burns, K. A., Stegeman, J. J., Tripp, B. W., Woodin, B. and Phinnley, C. 1992. The west Faimouth oil spill after 20 years; fate of fuel oil compounds and effects on animals. Marine Pollution Bulletin, 24: 607-614.

Vidali, M.2001. Bioremediation: An overview. Journal of Applied Chemistry, 73(7):11631172.

Yakubu, M. B. 2007. Biodegradation of Lagoma crude oil using pig dung. African Journal of Biotechnology, 6: 2821-2825. 